\section{EMBRYRIDDLE \\ Aeronautical University}

SCHOLARLY COMMONS

\section{International Journal of Aviation,} Aeronautics, and Aerospace

\title{
Impact of US Low Cost Carriers Entrance to the Airline Market in Colombia, South America
}

\author{
Carolina Anderson \\ Embry-Riddle Aeronautical University - Daytona Beach, lenzc@erau.edu \\ Tamilla Curtis \\ Embry Riddle Aeronautical University, curtist@erau.edu \\ Robert F. Moss \\ ERAU,MOSSR8@my.erau.edu \\ MaryJo O. Smith \\ Ypsilon Associates, drmaryjosmith@gmail.com \\ Gerson Mey \\ gerson_mey@hotmail.de
}

Follow this and additional works at: https://commons.erau.edu/ijaaa

Part of the Business Commons, and the Management and Operations Commons

\section{Scholarly Commons Citation}

Anderson, C., Curtis, T., Moss, R. F., Smith, M. O., \& Mey, G. (2017). Impact of US Low Cost Carriers Entrance to the Airline Market in Colombia, South America. International Journal of Aviation, Aeronautics, and Aerospace, 4(1). https://doi.org/10.15394/ijaaa.2017.1133

This Article is brought to you for free and open access by the Journals at Scholarly Commons. It has been accepted for inclusion in International Journal of Aviation, Aeronautics, and Aerospace by an authorized administrator of Scholarly Commons. For more information, please contact commons@erau.edu. 
Following a political and economic crisis in the late 1990s, many Colombian citizens decided to leave the country in search of opportunities, economic stability and most importantly, a secure place to raise a family. Most Colombian immigrants live in Florida, particularly in the Miami and the Orlando metropolitan areas.

With the increase in the Colombian population in the US, and the improvement of the economic and political situation between the two countries, US LCCs such as Spirit Airlines, Inc. (Spirit Airlines) and JetBlue Airways Corporation (JetBlue) saw the opportunity to enter the market in 2008 and 2009, respectively. This created direct competition with the Colombian traditional flag carrier Avianca and US legacy airlines operating in this market at that time, such as United Airlines, Delta Air Lines, and American Airlines.

The US-based low-cost carriers (LCCs), JetBlue and Spirit Airlines, used to be known for their no-frills, low-fare style, and for being domestic only airlines. JetBlue is also considered to be a low-cost hybrid airline since it displays some characteristics of full-service carriers. As such, JetBlue does offer some in-flight amenities including free drinks, snacks, and entertainment. In March of 2008, the U.S. Department of Transportation (DOT) awarded JetBlue and Spirit Airlines new routes to Colombia, their first routes to South America entered into force in April of 2009 (Santiago, 2008). At the same time, the U.S. DOT also granted United Airlines, previously Continental Airlines, and Delta Air Lines additional frequencies to increase their current offerings in the market. However, American Airlines lost seven of its US - Colombia frequencies as a result of the order, and US Airways was not granted permission to begin a direct route from Charlotte to Bogota, Colombia. Reacting to these changes, Avianca started a direct route from Bogota to Orlando, Florida in July 2011 that added to their existing routes from Miami and Fort Lauderdale.

After reaching market saturation in some areas, LCCs and airlines in general attempt to find new routes to fill their airplanes. International markets become very appealing because these routes are profitable, and legacy carriers have had dominance over these markets (Vasigh et al., 2010). The distance between Miami or Orlando and several major cities in Colombia were within the LCC normal flight range. Flying to Bogota is just a three-hour flight from Miami or a three and a halfhour flight from Orlando. The routes to Colombia appeared to be the right fit for a South American debut for the US LCCs. These relatively short routes also fit the maximum range of about five hours for the type of aircraft operated by LCCs, such as the Airbus A320 and the Boeing 737. According to Dennis (2007), "long-haul travel will be concentrated in the hands of a few key players" (page 23). Short-haul 
routes to Colombia provide LCCs the perfect opportunity to enter the international market without making drastic changes to their infrastructure.

In Colombia, Spirit Airlines entered the market by flying direct from Fort Lauderdale to Bogota and later to smaller Colombian towns, such as Armenia and Cartagena. The route allows passengers who live in these cities to take a direct flight to the US from their hometown, without connecting through a major city. According to Vasigh et al. (2010), the strategy is typical LCCs that expand their market share by targeting passengers who have not had the opportunity to use direct airline service before.

The purpose of this study is to analyze the impact of the US-based LCCs, such as Spirit Airlines and JetBlue, on the aviation passenger market between Florida and Colombia. In particular, the study investigates the effect on the market shares of Avianca, the Colombian national carrier, and American Airlines, which dominated players at the time of the LCCs entrance. The study examines the socioeconomic factors and other variables that affect a passenger demand including Colombian unemployment rate, GDP, and currency exchange rate. The airlinespecific analyses of the aviation passenger market between the Florida and Colombia were conducted including passenger demand, load factors, the frequency of flights, and other characteristics.

\section{Methodology}

\section{Data Collection}

The quantitative flight data was extracted from the Research and Innovative Technology Administration (RITA) databases of the US Department of Transportation's Bureau of Transportation Statistics. RITA databases provide information about both domestic and international airlines on their specific routes. The information includes number of passengers, amount of freight, mail, and other parameters. The demographic data was extracted from the Census Bureau and the CIA World Fact Book, including details on the Hispanic population in the US as well as the number of Colombians living in Florida.

Data for all flights from Colombia to the state of Florida in the US for the years of 2007 to 2015 was extracted using RITA databases. Since Spirit Airlines and JetBlue currently only offer direct flights from Florida to Colombia, the data was filtered selecting the airlines that cover these routes. These airlines are (1) Avianca, (2) American Airlines, (3) LAN Chile, and (4) LATAM Airlines, previously known as Aires (Aerovias de Integracion Aerovías de Integración Nacional). 
Other airlines that carried fewer passengers or had the routes approved but were not actively carrying passengers were not considered in this analysis. These airlines included LAN Peru, LAN Ecuador, Continental Airlines, United Airlines, Delta Air Lines, and USA 3000. A total of 2,026 flights were analyzed, and there was no missing data recorded for the parameters specified above.

\section{Procedures}

The passenger market share between Florida and Colombia for 2007 to 2015 for existing airlines were presented graphically with analyses of airlines' load factor, frequency of flights and other factors. A multiple regression analysis was performed to formulate a passenger demand equation for the routes between Florida and Colombia.

\section{Socio-Economic Factors}

According to the latest data of the U.S. Census Bureau (2010), among the 12.3 million Hispanics in the US in 2010, those of Colombian origin were the largest South American group with a population of 908,734, followed by Ecuadorians at 565,000, and Peruvians at 531,000. The overall Colombian population in the US increased from 470,684 in 2000 to 908,734 in 2010. This is an increase of 438,050 people or $93 \%$ between $2000-2010$. In the State of Florida, the total population was $18,801,310$ in 2010 with the total Hispanic population $4,223,806$ of which 300,414 were Colombians, representing a $7 \%$ of the Hispanic population in the state. The number of Colombians living in Florida had an increase of $116 \%$ increase between 2000-2010.

In addition to population growth, other factors such as an unemployment rate, GDP, and currency exchange can affect the passenger demand (Vasigh et al., 2010). Leisure travel tends to be more elastic since leisure passengers are more likely to postpone a trip in response to higher airfares. However, international trips tend to be less elastic since alternative modes of transportation would not be as available for international routes (Department of Finance Canada, 2008).

Colombia had a political and economic crisis in the late 1990's and the early 2000s. Its unemployment rate reached a historical high of $17.87 \%$ in January of 2001. Since then, the economy has been recovering, and unemployment rates reached a historical low of $7.30 \%$ in late 2015 (see Figure 1). 


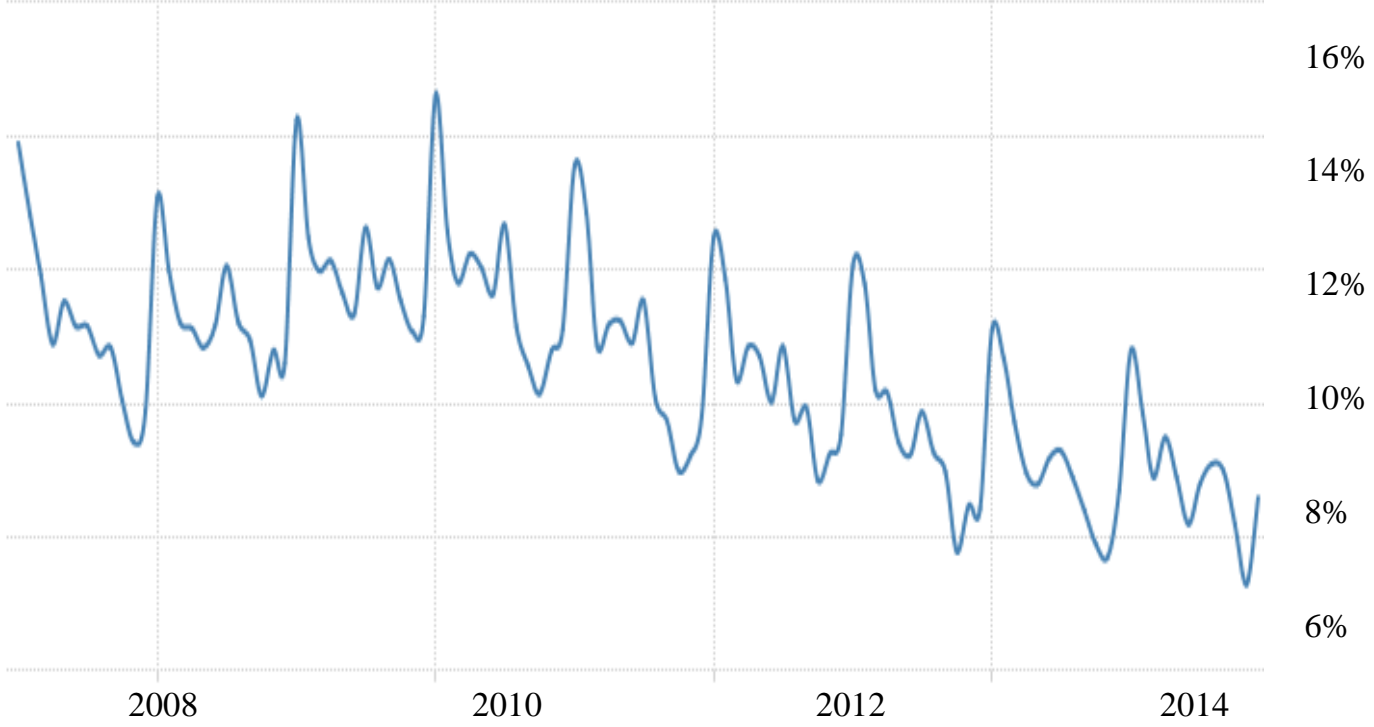

Figure 1. Unemployment Rate of Colombia. Note: from Tradingeconomics, 2016.

Colombia's average annual GDP growth was $4.12 \%$ since 2000, reaching a historical high of $7.70 \%$ in September of 2006 and a record low of $0.10 \%$ in December of 2008. Colombia has a free market economy with major commercial and investment ties to the United States. The transition from a highly regulated economy has been underway for more than 15 years. Colombia's average annual economic growth rate of over 5\% from 2002 to 2007 can be attributed to an increase in domestic security, resulting in greater foreign investment, prudent monetary policy, and export growth. Colombia reported a trade surplus equivalent to 326 million USD in July of 2011 (Tradingeconomics, 2011). Colombia's major exports are petroleum, coffee, coal, nickel, gold, and nontraditional exports (e.g. flowers, semiprecious stones, sugar, and tropical fruits). Colombia's major imports are industrial and transportation equipment, consumer goods, chemicals, paper products, fuels, and electricity. Its principal trading partners are the United States, the European Union, Venezuela, China, and Mexico. The total population in Colombia was last reported at 45.9 million people in 2010 from 16.0 million in 1960, changing 187\% during these 50 years (Tradingeconomics, 2011).

\section{Aviation Market Florida to Colombia}

Passenger Market Share. The number of passengers carried and the market share per year from 2007 to 2015 by the six airlines analyzed are presented 
in Table 1. Figure 2 depicts and compares the market share among airlines for the same period.

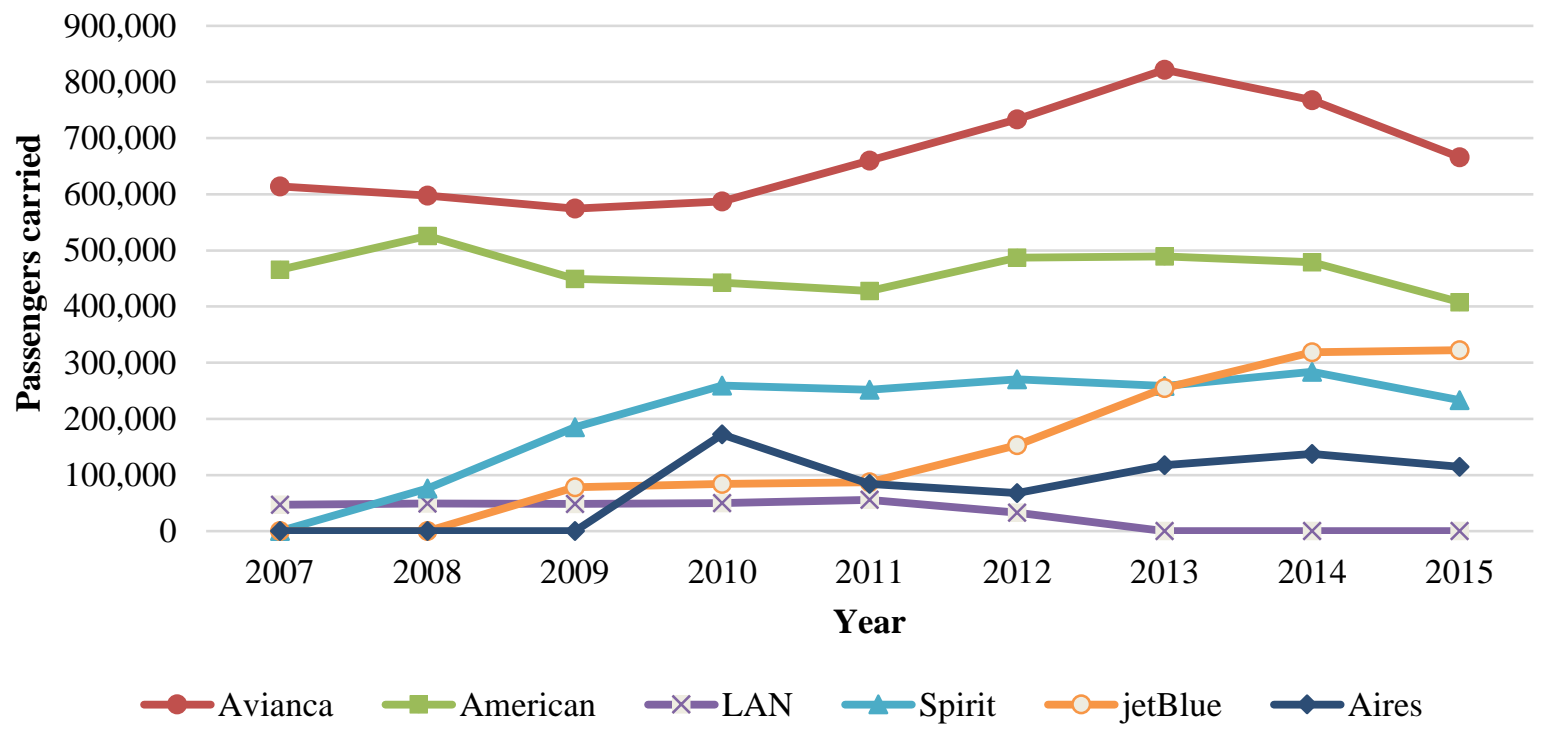

Figure 2. Airline Market Share between Florida and Colombia, 2007 to 2015. Note: from RITA database of the Bureau of Transportation Statistics, 2016.

In 2007, the aviation market between Colombia and Florida, US was dominated by the national flag carriers Aerovías Nacionales de Colombia (Avianca) and American Airlines, each carrying 614,233 and 465,854 passengers, respectively, for a total market share of $54 \%$ for Avianca and $41 \%$ for American Airlines. LAN Chile had a 4\% market share in 2007 with 47,072 passengers carried that year.

In the second quarter of 2008 Spirit Airlines entered the Colombian market. In 2008 Avianca carried 597,569 passengers between Florida and Colombia, representing $48 \%$ of the market. American Airlines came in second with 525,798 passengers and $42 \%$ market share. In the first year of entering the Colombian market in 2008 Spirit Airlines was able to capture 6\% with 76,075 passengers, followed by LAN Chile with $4 \%$ market share and 49,125 passengers. Spirit Airlines entry could play an effect in decreasing the Avianca market share within one year from 54\% in 2007 to 48\% in 2008. At the same time, American Airlines had a slight $1 \%$ increase and LAN Chile market share remained unchanged at $4 \%$. 
Table 1

Florida, US-Colombia Passengers Carried, 2007 to 2015

\begin{tabular}{llllllll}
\hline Year & Avianca & $\begin{array}{l}\text { American } \\
\text { Airlines }\end{array}$ & LAN & $\begin{array}{l}\text { Spirit } \\
\text { Airlines }\end{array}$ & JetBlue & $\begin{array}{l}\text { LATAM/ } \\
\text { Aires }\end{array}$ & $\begin{array}{l}\text { Total } \\
\text { Market }\end{array}$ \\
\hline $\mathbf{2 0 0 7}$ & 614,233 & 465,854 & 47,072 & - & - & - & $1,127,159$ \\
$\mathbf{\%}$ & $54 \%$ & $41 \%$ & $4 \%$ & & & & $100 \%$ \\
$\mathbf{2 0 0 8}$ & 597,569 & 525,798 & 49,125 & 76,075 & - & - & $1,248,567$ \\
$\mathbf{\%}$ & $48 \%$ & $42 \%$ & $4 \%$ & $6 \%$ & & & $100 \%$ \\
$\mathbf{2 0 0 9}$ & 574,396 & 449,037 & 48,756 & 185,207 & 78,209 & - & $1,335,605$ \\
$\mathbf{\%}$ & $43 \%$ & $34 \%$ & $4 \%$ & $14 \%$ & $6 \%$ & & $100 \%$ \\
$\mathbf{2 0 1 0}$ & 587,395 & 442,560 & 49,715 & 259,425 & 83,751 & 172,097 & $1,594,943$ \\
$\mathbf{\%}$ & $37 \%$ & $28 \%$ & $3 \%$ & $16 \%$ & $5 \%$ & $11 \%$ & $100 \%$ \\
$\mathbf{2 0 1 1}$ & 660,165 & 427,340 & 55,609 & 252,020 & 86,989 & 83,754 & $1,565,877$ \\
$\mathbf{\%}$ & $42 \%$ & $27 \%$ & $4 \%$ & $16 \%$ & $6 \%$ & $5 \%$ & $100 \%$ \\
$\mathbf{2 0 1 2}$ & 733,660 & 486,980 & 33,175 & 270,511 & 152,964 & 67,670 & $1,744,960$ \\
$\mathbf{\%}$ & $42 \%$ & $28 \%$ & $2 \%$ & $16 \%$ & $9 \%$ & $4 \%$ & $100 \%$ \\
$\mathbf{2 0 1 3}$ & 821,752 & 489,576 & & 258,518 & 254,888 & 117,321 & $1,942,055$ \\
$\mathbf{\%}$ & $42 \%$ & $25 \%$ & - & $13 \%$ & $13 \%$ & $6 \%$ & $100 \%$ \\
$\mathbf{2 0 1 4}$ & 767,547 & 478,971 & - & 283,814 & 318,864 & 137,422 & $1,986,618$ \\
$\mathbf{\%}$ & $39 \%$ & $24 \%$ & - & $14 \%$ & $16 \%$ & $7 \%$ & $100 \%$ \\
$\mathbf{2 0 1 5}$ & 666,067 & 407,950 & - & 233,580 & 322,339 & 114,803 & $1,744,739$ \\
$\mathbf{\%}$ & $38 \%$ & $23 \%$ & - & $13 \%$ & $18 \%$ & $7 \%$ & $100 \%$ \\
\hline
\end{tabular}

Note: from RITA database of the Bureau of Transportation Statistics, 2016.

In 2009, JetBlue entered the market, and Avianca had a further reduction in market share to $43 \%$, followed by American Airlines with $34 \%$, and LAN Chile with 4\%. In contrast, Spirit Airlines' increase was more than double to 185,207 passengers or $14 \%$ market share. JetBlue debuted with 78,209 passengers and 6\% market share during its first year with routes from Orlando to Bogota only a few days a week.

In 2010, Avianca had a further reduction in market share to $37 \%$ despite an increase in the number of passengers carried. American Airlines had a decrease to $28 \%$ in market share while Spirit Airlines continue to have an increase in the market share and the total number of passengers carried. JetBlue had a $1 \%$ decrease in the market share although the number of passengers carried had increased. That year, Colombian airline Aires entered the market and immediately captured $11 \%$ of the market with 172,097 passengers.

In 2011, Avianca began its non-stop flights from Bogota to Orlando and increased market share from $37 \%$ to $40 \%$. American Airlines' share stayed at $27 \%$. Aires was bought by the LAN group and later was renamed LAN Colombia. Today, it is named LATAM airline. LAN Chile's market share was limited to $1 \%$, and routes were subsequently on acquired by its sister company, LATAM Colombia. 
As of 2015, Avianca maintains the majority of the market share with 38\%, followed by American Airlines with 23\%, JetBlue with 18\%, Spirit Airlines with $13 \%$, and LATAM with $7 \%$. While Avianca's market share appeared to have decreased from $54 \%$ in 2007 to $38 \%$ in 2015, its number of passengers carried increased by $8.43 \%$ between 2007 and 2015. American Airlines displayed a decrease as well from $41 \%$ in 2007 to $23 \%$ in 2015 . However the number of passengers carried also dropped by $12 \%$.

Passenger Demand. The average number of travelers per year between Florida and Colombia for the specific airlines analyzed in this study has increased from $1,128,283$ in 2007 to $1,744,910$ in 2015, which is a 616,627 passenger or $54.7 \%$ increase in 8 years (see Figure 3 ).

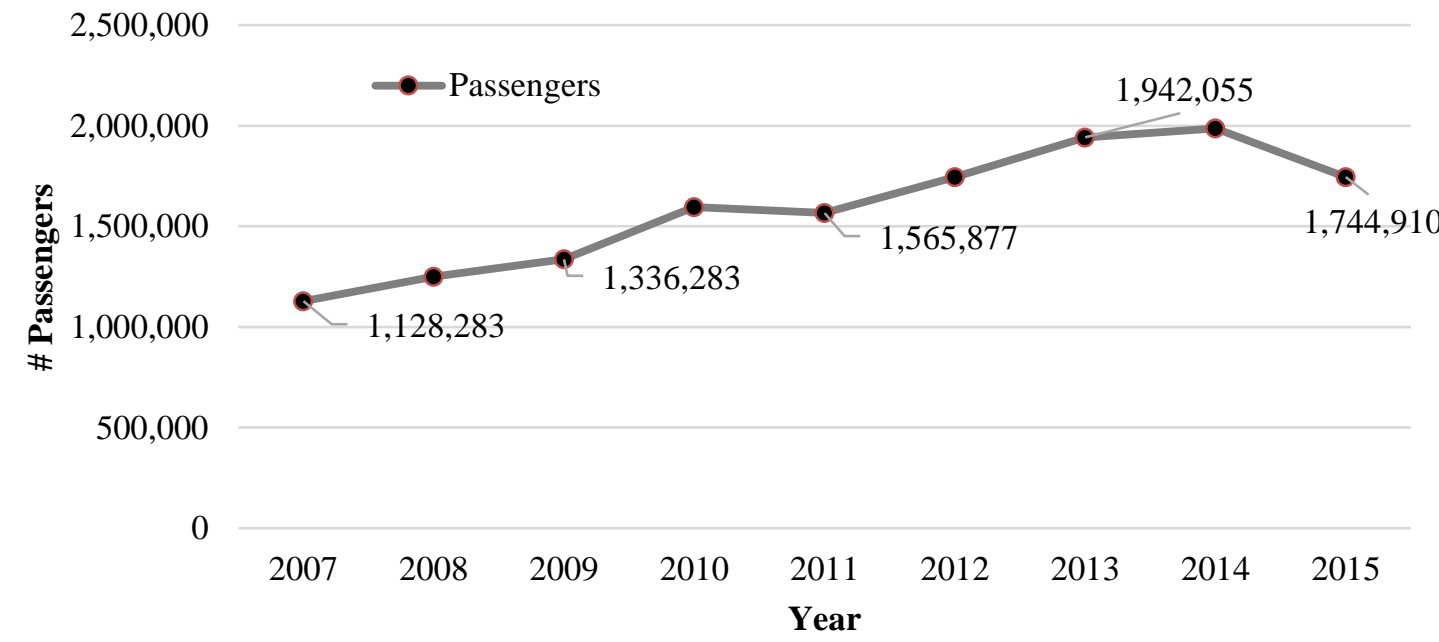

Figure 3. Total Number of Passengers between Florida and Colombia, 2007 to 2015. Note: from RITA database of the Bureau of Transportation Statistics, 2016.

Load Factors. The average load factors for all the airlines under the investigation is presented in Figure 4. 


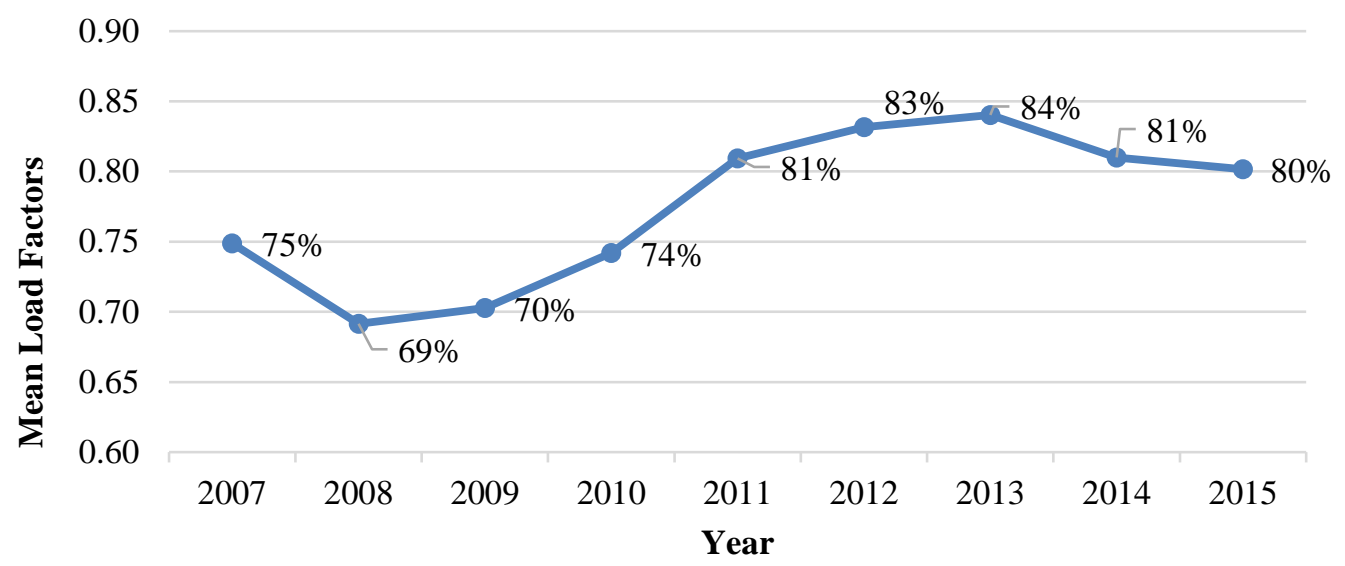

Figure 4. Mean Load Factors between Florida and Colombia, 2007 to 2015. Note: from RITA database of the Bureau of Transportation Statistics, 2016.

After analyzing the average load factors for each carrier separately, it was found that the load factor for the flag carrier Avianca has increased by $15.0 \%$. Additionally, for American Airlines, it decreased by 0.7\%; for Spirit Airlines, it rose by $17.4 \%$ from 2008 to 2015; for JetBlue, have increased by $2.8 \%$ from 2009 to 2015 . Further, for LAN Chile the load factors have increased by $17.6 \%$ from 2007 to 2015; and for Aires, the load factors increased by $19.5 \%$ from 2010 to 2014 (information unavailable before and after this period).

Frequencies of Flights. The annual frequency of flights between Florida and Colombia for all selected airlines is shown in Figure 5. As seen in the Figure, the frequency of flights has been increasing since 2007, with the highest increase in 2014 and a slight decrease the following year.

Airfares. Average airfare information for international airlines is restricted and not publicly available. Therefore, specific average airfare changes for the routes between Florida and Colombia were not analyzed. However, average domestic airfares for the Puerto Rican market (San Juan) between 1997 and the first quarter of 2011 were accessible and analyzed. The Puerto Rican market was selected as a proxy for the Colombian market for some reasons. Although Puerto Rico is an island in the Caribbean and Colombia is located in Northern South America bordering the Caribbean Sea, the countries have some similarities in regards to the passenger traffic to and from the US. Both countries are Spanish speaking and have close family and business relations with mainland US and especially Florida. Both markets were dominated by mostly legacy carriers before US LCCs Spirit Airlines, and JetBlue entered the Puerto Rican market in November of 2001 and December of 2009, while in Colombia, Spirit Airlines and JetBlue entered the market in 2008 
and 2009 respectively. With a growth of nearly 60\% since 2000 (Census, 2010), the Puerto Rican population is increasing at a fast pace in Florida, similar to the Colombians in the same state.

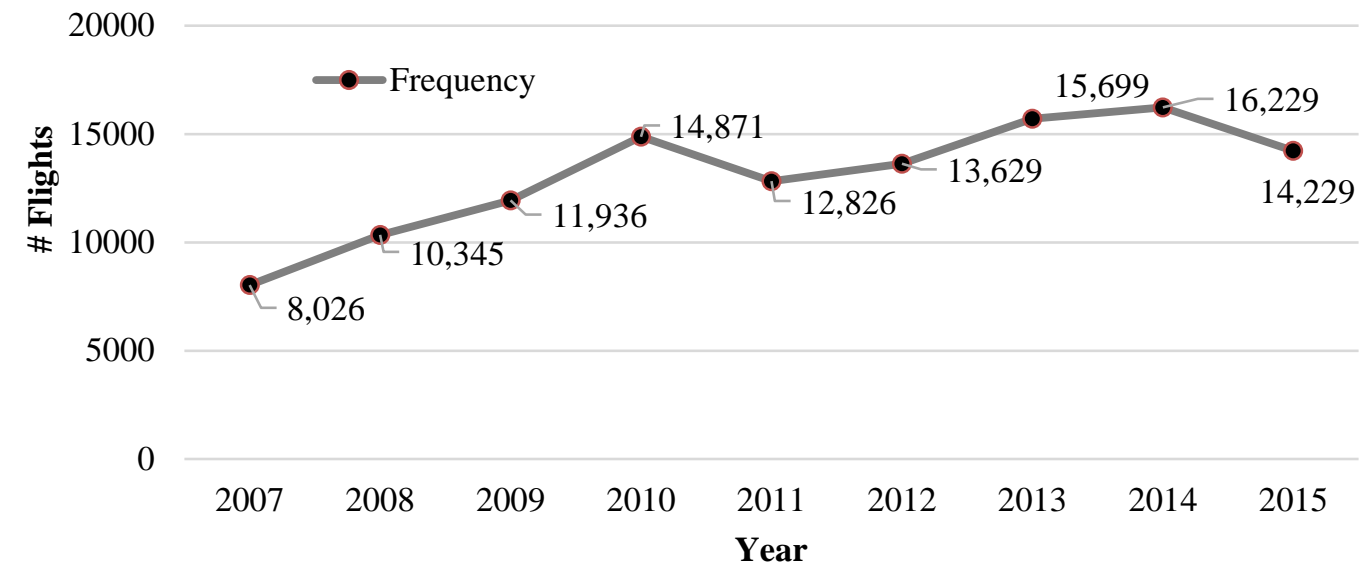

Figure 5. Frequency of Flights between Florida and Colombia, 2007 to 2015. Note: from RITA database of the Bureau of Transportation Statistics, 2013.

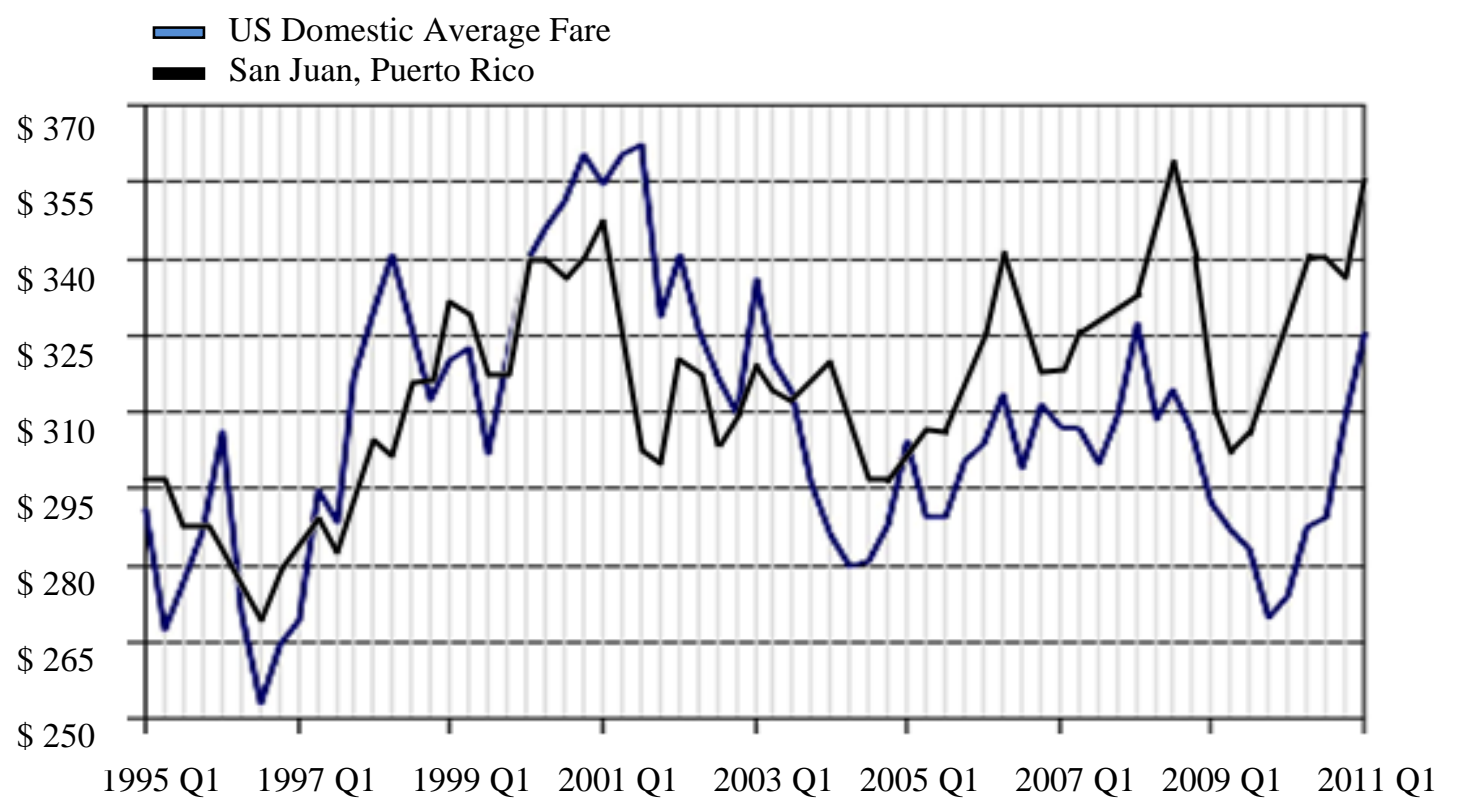

Figure 6. Average US Domestic Airfares, Q1 1995 to Q1 2011. Note: from Bureau of Transportation Statistics, 2011.

As seen in Figure 6, average US domestic airfares and airfares from San Juan, Puerto Rico were at their peak in the first quarter of 2001 at $\$ 347.69$ and 
began decreasing afterward. Airfares reached their lowest point since 1996 during the first quarter of 2005 and in the second quarter of 2009 at $\$ 301.82$. Before 2003, the average airfares for Puerto Rico were above the domestic US average airfare. However, since 2003, they have remained below the national average. Between 2001 and 2010, after LCCs Spirit Airlines (2001) and JetBlue (2009) entered the market, the average airfare in San Juan, Puerto Rico has decreased by $10 \%$. The biggest change in average airfare occurred between 2001 and 2004, a 30\% decrease.

When analyzing the impact on average airfare after LCCs have entered the market, the effect of revenue management and flow of the network have to be taken into consideration, or any analysis utilizing traditional methods could result in misleading information (Gorin \& Belobaba, 2008). Traditionally, after LCCs enter a market, they can offer lower airfares due to their simplified structure. Therefore, airlines competing in the same market see themselves forced to lower their airfares to remain competitive (Vasigh et al., 2010). As seen in the Puerto Rican market and other markets, these low airfares usually have an impact on overall average airfares.

\section{Passenger Demand Analysis}

A regression analysis with multiple dependent variables was performed to formulate a demand equation for the passenger routes between Florida and Colombia. The dependent variable was quarterly passenger demand between 2007 and 2010. The independent variables included quarterly Colombian GDP between 2007 and 2010 and the exchange rate between the Colombian peso and US dollar in dollars for the same period. The GDP utilized is the one for Colombia because it is assumed that most passengers are Colombian travelers visiting relatives in Colombia or the US. Tourism of US citizens in Colombia has increased in the last five years. However, it is still relatively low due to the perceived security issues. For example, in 2006, the US Department of State issued a travel warning to Colombia, saying that "violence by narcoterrorist groups and other criminal elements [continued] to affect all parts of the country" (US Department of State, 2006).

Since airfare data was not available, a dummy variable for the average price was utilized after the entrance of US LCCs into the Colombian market in the Q2 2008. The common price dummy variable was given the value of zero before Q2 2008 and the value of 1 after that to determine the effect of LCCs on average price (see Appendix A). Three other dummy variables were utilized to determine the effect of seasonality. Regression results indicated an overall model of six predictors that significantly predict the passenger demand, $R^{2}=0.942, R^{2} \operatorname{adj}=0.904, F(6)=$ 
24.56, $p<.001$. This model accounted for $94 \%$ of variance in passenger demand. A summary of the regression model is presented in Appendix B.

The residual plots did not display any trend in the residuals indicating that there was any autocorrelation in the regression. This was confirmed by the DurbinWatson number of 1.95 which falls within the acceptable range of 1.5 to 2.5.

The demand equation for the route analyzed is as follows:

$$
\begin{gathered}
\text { Passenger Demand (Florida - Colombia) } \\
=-14,224.16 * \text { PriceDummyAfterLLC } \\
+1.77 E-6 * G D P-2.98 E 8 * \text { ExchangeRate }-69,940.74 * Q 1 \\
-34,106.98 * Q 2+25,384.08 * Q 3+78,825.41
\end{gathered}
$$

Standardized or $Z$-values were also utilized, and the standardized demand equation obtained was:

$$
\begin{aligned}
& \text { Standardized Passenger Demand (Florida - Colombia) } \\
& \quad=-0.26 * \text { PriceDummyAfterLLC }+.95 * \text { GDP }-.25 \\
& \quad * \text { ExchangeRate }-1.2 * Q 1-.61 * Q 2+.46 * Q 3+.53
\end{aligned}
$$

The advantage of utilizing standardized or $Z$-values is that the numbers are more manageable and easier to compare with each other. To forecast demand based on a demand equation, the non-standardized values should be utilized (Vasigh et al., 2010). The results of the regression are shown in Appendix B. The $t$-statistic is a measure of the accuracy of a statistical estimate. Therefore, a significant $t$-value indicates that the variable in question influences the independent variable while controlling for other explanatory variables. Of the six independent variables that are included in the regression, three were statistically significant with $p<0.05$. These variables are GDP and two seasonal dummy variables (Q1 and Q2). In general, if an independent variable's $t$-test is not statistically significant, it can be excluded from the model unless there are theoretical reasons to include these variables. To include these variables in the model, multicollinearity was checked. Multicollinearity exists when two or more independent variables are highly correlated (Vasigh et al., 2010). The Variance Inflation Factor (VIF) aids in the detection of multicollinearity. A VIF above 4 indicates the presence of high multicollinearity. In this study, the VIF statistic shows that there is no multicollinearity among variables. 
In summary, three variables affect passenger demand significantly, Q1, Q2, and GDP. Q1 and Q2 account for seasonality of air travel, and GDP accounts for country's economic production and the total income of potential customers.

\section{Discussion}

The purpose of this study was to analyze the impact of LCCs Spirit Airlines and JetBlue on the aviation passenger market between Florida and Colombia. As seen in Figure 2, before 2008, the Colombian flag carrier Avianca and American Airlines dominated the market between Florida and Colombia. Also, LAN Chile maintained a $4 \%$ market share in 2007, 2008, and 2009, but it decreased to $3 \%$ in 2010 and $1 \%$ in the first half of 2011. LAN Chile acquired the Colombian airline Aires that entered the market in 2010 and attained an 11\% market share the same year (Sobie, 2010).

According to LAN's executives, the Colombian market is very attractive. It had a significant increase of $35 \%$ or 7.4 million passengers in the first half of 2010 . Many factors are contributing to the expansion of aviation passenger market between U.S. and Colombia. Colombia's average annual economic growth rate of over 5\% from 2002 to 2007 can be attributed to an increase in domestic security, resulting in greater foreign investment, prudent monetary policy, and export growth. Colombia reported a trade surplus equivalent to \$US 326 million in July 2011. A much improved socio-economic situation in a country that is located on the very northern corner of South America and at a relatively short distance from Florida, approximately 3.5-hour flight, contributes to making Colombia a very appealing destination for airlines including US LCCs that have encountered market saturation in other areas. These carriers are in search for new destinations without having to alter their infrastructure and mode of operation. In addition, an increase in the Hispanic population, especially an overall growth in the Colombian population in the United States of over $93 \%$ in ten years with a significant concentration in Florida, assures that the passenger market growth is not a transitory indication. Florida also offers year-round attractions that are family friendly, especially for Hispanics due to their dominance among immigrants in this region.

Also, to promote the cooperation between two countries, several air transport bilateral agreements were signed between the US and Colombia that began in 1956 with amendments in 2000 and 2007. Those agreements led to an open skies agreement signed in May 2011 that took effect at the end of 2012 (US State Department, 2002). According to the US Department of Transportation, "Colombia is a major aviation partner of the United States; every year more than two million passengers travel between our two countries. In fact, the United States 
is Colombia's top aviation market, and Colombia is the second largest aviation market for the United States in South America” (Fernandez, 2011, p. 1).

As a result of positive changes, the total passenger market between Florida and Colombia increased between 2007 and 2015 from 1.127 million passengers to 1.744 million. In 2015 the largest market share was held by Avianca (38\%), followed American Airlines (23\%), JetBlue (18\%), Spirit Airlines (13\%) and LATAM Airlines (Aires) (7\%). However, despite the growth in the passenger market, Avianca and American Airlines had a decrease in their market shares between 2007 and 2015. Avianca had a decline from 54\% to 38\%, while American Airlines had a decrease from $41 \%$ to $23 \%$ (see Table 1). Spirit Airlines had its market share increased from $6 \%$ in 2008 to $13 \%$ in 2015, while JetBlue had the market share increased from 6\% in 2009 to $18 \%$ in 2015.

The mean load factors did not change drastically for any of the airlines between 2007 and 2010 and appear to be steady around $70 \%$ for the legacy carriers and slightly higher around $80 \%$ for the LCCs.

The results of the study confirmed that LCCs present a strong competition to traditional airlines. Also, the study formulated the demand equation that takes into consideration population of Colombia in the U.S., currency exchange rate, the level of unemployment, and GDP. The study found that GDP and seasonality play a significant role in air travel passenger demand. The major limitation of this study is the lack of publically available airfare information for international routes. Future studies could incorporate international airfare information, extended period, and additional factors which potentially can affect passenger demand.

\section{Conclusion}

The Florida-Colombian aviation market has a significant increase in a passenger travel from 2007. New players emerged in the market such as Spirit Airlines and JetBlue. Avianca and American Airlines remained dominant carriers in this market despite losing some of their market shares to US LCCs. The flag carrier, Avianca, is a very traditional airline. On Avianca's flights from Florida to Colombia, a full hot meal and a free selection of beer and wine is offered in addition to two free checked bags even to coach passengers. American Airlines is popular with American travelers because of familiarity, trust, and frequent flyer loyalty programs.

This study contributes to the literature on the LCCs impact on the example of Spirit Airlines and JetBlue expansion to the Colombian market. The results of 
this study confirmed that Spirit Airlines and JetBlue present a strong competition to traditional carriers such as Avianca and American Airlines. LCCs attempt to find new routes and short-haul routes to Colombia provide LCCs the perfect opportunity to enter the international market without making drastic changes to their infrastructure. Spirit Airlines initiated direct flights from smaller Colombian towns to the U.S., which provided the opportunity passengers to avoid connecting through a hub. While Spirit Airline and JetBlue are increasing their presence in the Colombia-Florida aviation market, the market shares of traditional carriers Avianca and American Airlines are decreasing. The recovering economy in Colombia, an increase in GDP, a rapid growth of Colombian population in the U.S., governmental regulations and other factors contribute to the overall increase in aviation passenger market. However, despite the favorable environment, the entrance and growth of LCCs in Colombia present a major challenge to traditional carriers. 


\section{References}

Dennis, $N$ (2007). Competition and change in the long haul markets in Europe. Journal of Air Transport, 12(2), page 4-26.

Department of Finance Canada (2008). Air travel demand elasticities. Concepts, issues and measurement. Retrieved from http://www.fin.gc.ca/consultresp/airtravel/airtravStdy_1-eng.asp.

Fernandez, J (2011). U.S., Colombia signs Open Skies Agreement [Web log post]. Retrieved from http://blogs.state.gov/index.php/site/entry/colombia_open_skies.

Gorin, T, \& Belobaba, P (2008). Assesing Predetaion in Airline Markets with Low-Fare Competition. Doctoral Dissertation, Massachusetts Institute of Technology. Retrieved from ProQuest.

Research and Technology Administration-Bureau of Transportations Statistics (2016). T-100 International Segment, all Carriers. [Data file] Retrieved from http://www.transtats.bts.gov/Tables.asp?DB_ID=111\&DB_Name=Air\%2 0Carrier\%20Statistics\%20\%28Form\%2041\%20Traffic\%29\%20All\%20Carriers\&DB_Short_Name=Air\%20Carriers.

Santiago, A (2008, March). JetBlue, Spirit win Colombia flights. Retrieved from: http://www.aviationweek.com/aw/generic/story_generic.jsp?channel=com m\&id=news/COLO03068.xml\&headline=JetBlue, \%20Spirit\%20Win $\% 20$ Colombia\%20Flights.

Sobie, B (2010). LAN to acquire Colombia's Aires. Serious about Aviation. Retrieved from http://www.businesswire.com/news/home/20101027007341/en/LANAirlines-Announces-Agreement-Acquire-Colombian-Airline

Tradingeconomics (2016). Graphic illustration of Colombian unemployment. Retrieved from http://tradingeconomics.com.

U.S. Census Bureau. (2010). U.S. Census. Retrieved from http://www.census.gov.

U.S. Central Intelligence Agency (2011). The world fact book. Dulles, VA: Potomac Books. 
International Journal of Aviation, Aeronautics, and Aerospace, Vol. 4 [2017], Iss. 1, Art. 1

U.S. Department of State. (2006). Colombia travel warning. Retrieved from https://www.osac.gov/Pages/ContentReportPDF.aspx?cid=4467.

Vasigh, B., Fleming, K., and Tacker, T. (2010). Introduction to air transport economics (2nd ed.). Burlington, VT: Ashgate. 


\section{Appendix A}

Dataset for Demand Curve for the Route between Colombia and Florida.

\begin{tabular}{llllllll}
\hline Quarter & Demand & GDP $(\$-U S)$ & $\begin{array}{l}\text { Exchange } \\
\text { Rate }^{1}\end{array}$ & $\begin{array}{l}\text { Price } \\
\text { Dummy }^{2}\end{array}$ & Q1 & Q2 & Q3 \\
\hline Q1 2007 & 264,144 & $2.11 \mathrm{E}+11$ & .000454545 & 0 & 1 & 0 & 0 \\
Q2 2007 & 265,748 & $2.11 \mathrm{E}+11$ & .000476190 & 0 & 0 & 1 & 0 \\
Q3 2007 & 312,227 & $2.11 \mathrm{E}+11$ & .000500000 & 0 & 0 & 0 & 1 \\
Q4 2007 & 289,430 & $2.11 \mathrm{E}+11$ & .000512821 & 0 & 0 & 0 & 0 \\
Q1 2008 & 295,580 & $2.36 \mathrm{E}+11$ & .000500000 & 0 & 1 & 0 & 0 \\
Q2 2008 & 280,716 & $2.36 \mathrm{E}+11$ & .000540541 & 1 & 0 & 1 & 0 \\
Q3 2008 & 351,339 & $2.36 \mathrm{E}+11$ & .000526316 & 1 & 0 & 0 & 1 \\
Q4 2008 & 320,932 & $2.36 \mathrm{E}+11$ & .000540541 & 1 & 0 & 0 & 0 \\
Q1 2009 & 282,360 & $2.34 \mathrm{E}+11$ & .000384615 & 1 & 1 & 0 & 0 \\
Q2 2009 & 333,011 & $2.34 \mathrm{E}+11$ & .000454545 & 1 & 0 & 1 & 0 \\
Q3 2009 & 376,676 & $2.34 \mathrm{E}+11$ & .000444444 & 1 & 0 & 0 & 1 \\
Q4 2009 & 343,550 & $2.34 \mathrm{E}+11$ & .000454545 & 1 & 0 & 0 & 0 \\
Q1 2010 & 335,539 & $2.89 \mathrm{E}+11$ & .000500000 & 1 & 1 & 0 & 0 \\
Q2 2010 & 379,915 & $2.89 \mathrm{E}+11$ & .000526316 & 1 & 0 & 1 & 0 \\
Q3 2010 & 448,529 & $2.89 \mathrm{E}+11$ & .000555556 & 1 & 0 & 0 & 1 \\
Q4 2010 & 430,960 & $2.89 \mathrm{E}+11$ & .000526316 & 1 & 0 & 0 & 0 \\
\hline
\end{tabular}

${ }^{1}$ Pesos to $\$$-US

${ }^{2}$ After LLCs entered 


\section{Appendix B}

Statistical Analysis Results.

Model Summaryb

\begin{tabular}{|c|c|c|c|c|c|c|c|c|}
\hline \multirow[t]{2}{*}{$\overline{\text { Model }}$} & \multirow[b]{2}{*}{$R$} & \multirow[b]{2}{*}{$R^{2}$} & \multirow[b]{2}{*}{$R^{2}$ Adjusted } & \multicolumn{4}{|c|}{ Change Statistics } & \multirow[b]{2}{*}{$\begin{array}{l}\text { Durbin- } \\
\text { Watson }\end{array}$} \\
\hline & & & & $\begin{array}{l}\text { Std.Error } \\
\text { Estimate } \\
\end{array}$ & $R^{2}$ Change & $F_{\text {Change }} d f_{1}$ & $\begin{aligned} & \text { Sig. } \\
& d f_{2} F_{\text {Change }} \\
&\end{aligned}$ & \\
\hline 1 & $.971^{\mathrm{a}}$ & .942 & .904 & 17,139 & .942 & 24.5576 & $\begin{array}{ll}9 & .00 \\
\end{array}$ & 1.95 \\
\hline
\end{tabular}

ANOVA ${ }^{\text {b }}$

\begin{tabular}{lllllll}
\hline \hline Model & & Sum of Squares & $d f$ & Mean Square & $F$ & Sig. \\
\hline 1 & Regression & $4.33 \mathrm{E} 10$ & 6 & $7.21 \mathrm{E} 19$ & 24.56 & $.000^{\mathrm{a}}$ \\
& Residual & $2.64 \mathrm{E} 19$ & 9 & $293,748,317$ & & \\
& Total & $4.59 \mathrm{E} 10$ & 15 & & & \\
\hline \hline
\end{tabular}

a. IVs / Predictors (Constant) : Q3, GDP (\$-US), Q2, Exchange Rate Pesos to \$US, Q1, Price Dummy after LLCs Entered

$b$. Dependent Variable: Passenger Demand

\begin{tabular}{|c|c|c|c|c|c|c|c|}
\hline \multirow[t]{2}{*}{ Model } & \multicolumn{2}{|c|}{$\begin{array}{l}\text { Unstandardized } \\
\text { Coefficients }\end{array}$} & \multirow{2}{*}{$\begin{array}{l}\text { Stand. } \\
\text { Coefficients } \\
\text { Beta }\end{array}$} & \multirow[t]{2}{*}{$t$} & \multirow[t]{2}{*}{ Sig. } & \multicolumn{2}{|c|}{$\begin{array}{c}\text { Collinearity } \\
\text { Statistics } \\
\end{array}$} \\
\hline & B & Std. Error & & & & Tolerance & eVIF \\
\hline (Constant) & 78,825 & 57,232 & & 1.38 & .202 & & \\
\hline GDP (\$-US) & $1.77 \mathrm{E}-6$ & .000 & .96 & 7.12 & .000 & .42 & 2.36 \\
\hline $\begin{array}{l}\text { Exchange } \\
\text { Pesos to } \$\end{array}$ & $-2.99 \mathrm{E} 8$ & $\begin{array}{l}139,633,65 \\
4\end{array}$ & -.246 & -2.14 & .061 & .43 & 2.34 \\
\hline $\begin{array}{l}\text { Price Dummy } \\
\text { LLCs entered }\end{array}$ & $-14,225$ & 14,211 & -.123 & -1.00 & .34 & .66 & 1.52 \\
\hline Q1 & $-69,941$ & 15,140 & -.565 & -4.62 & .001 & .67 & 1.50 \\
\hline Q2 & $-34,107$ & 12,186 & -.276 & -2.80 & .021 & .35 & 2.82 \\
\hline Q3 & 25,384 & 12,122 & .205 & 2.09 & .066 & .48 & 2.07 \\
\hline
\end{tabular}

